\title{
AIRPORT PASSENGER EXPERIENCE MODEL FOR TERMINAL LOW- COST CARRIER (STUDY CASE AT TERMINAL 1 SOEKARNO-HATTA INTERNATIONAL AIRPORT)
}

\author{
Mora Yolanda Sagala, Ina Primiana Sagir, Iman Chaerudin \\ Universitas Padjadjaran Bandung Jawa Barat Indonesia \\ Email : morayolanda27@gmail.com, ina.sagir@fe.unpad.ac.id, \\ iman.chaerudin@ubs-usg.ac.id
}

\begin{abstract}
Introduction : The high traffic of flight movements and the number of airport passengers around the world are placed in very high demands on the airport industry business. For example the airport operator PT. Angkasa Pura II (Persero) or AP II is trusted to manage 19 airports and airport-related services to concentrate their service business on customers (Customer Centric Organization).

Objective : This study aims to obtain the Airport Passenger Experience Model in Terminal 1 of Soekarno-Hatta International Airport as a Low-Cost Carrier Terminal. Development of a passenger activity service model to address the gap between the level of importance and service perceived by business and leisure passenger types at all travel touch points in service processing activities and nonprocessing activities.
\end{abstract}

Method: This study uses 50 service attributes and 100 samples of respondents. The questionnaires were distributed twice. The first questionnaire uses the Quality Function Deployment (QFD) method to determine the performance of each service attribute through identification of passenger needs and desires (Needs). The second questionnaire uses the Analytic Hierarchy Process (AHP) to obtain a ranking or priority order based on the level of importance of airport passengers (Importance). Results : The results of the formulation of the House of Quality (HoQ) from a combination of QFD and AHP analysis methods get 5 priority programs (Panca Programs) from 17 Needs \& Importance technical responses, including Customer Centric, Strategic Approach to Customer Service, Innovative, Sense of Place and Positive Ambiance. These have been adapted to the types of business passengers and leisure passengers at Terminal 1 Soekarno-Hatta Airport as a template for the Airport Passenger Experience Model for Low-Cost Carrier Terminals. If the manager of Terminal 1-BSH can carry out the five priority technical responses, then it can meet the needs of airport passengers by contributing $53.73 \%$ and if the sixth to tenth priority technical response is also carried out, it will increase the airport passenger experience by contributing as much as $84.80 \%$ as optimization of airport service performance at Terminal 1 Soekarno-Hatta Airport.

Conclusion : Based on the identification of the needs and expectations of Terminal 1-BSH passengers through the Quality Function Deployment (QFD) method, there are 20 service attributes that have a negative gap value or exceed the average satisfaction threshold. Out of the 50 indicators of passenger activity service processing, it shows that airport passengers are still dissatisfied with the services provided or there is a decrease in the quality-of-service performance. The proportion of passengers' dissatisfaction in the departure service area is higher than in the arrival area. 
Airport Passenger Experience Model for Terminal Low-Cost Carrier (Study Case at Terminal 1 Soekarno-Hatta International Airport)

Keywords : processing activities, non-processing activities, qfd, ahp, airport passenger experience

\section{Introduction}

Based on the 2018 IATA Tourism Economics Press Release report, it is estimated that the number of airplane passengers worldwide will triple to 8.2 billion by 2037 and economic activity supported by aviation is expected to be USD6.9 trillion . Meanwhile, in the Asia-Pacific region, Indonesia is expected to become a prominent performer, rising to the 10th largest in 2017 to the 4th largest in 2037 from the world aviation market as illustrated in Figure 1

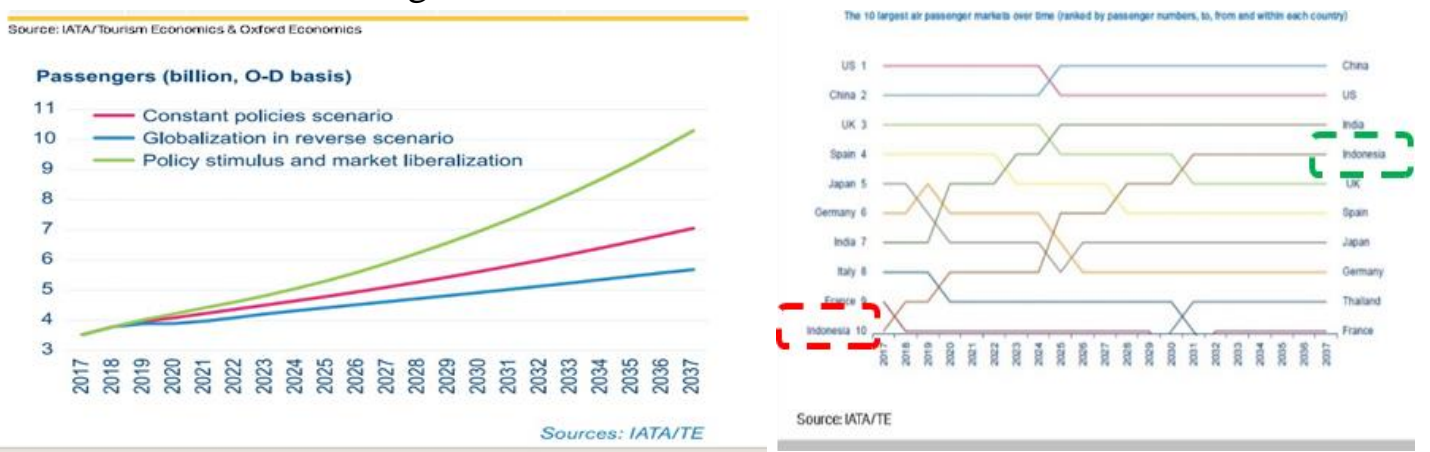

Figure 1. Estimated Number of Airplane Passenger \& Top 10 Largest Airplane Passenger in 2017-2037. Source: IATA/Tourism Economics \& Oxford Economics, 2018

The high traffic of flight movements and the number of airport passengers around the world are placed in very high demands on the airport industry business. For example the airport operator PT. Angkasa Pura II (Persero) or AP II is trusted to manage 19 airports and airport-related services to concentrate their service business on customers (Customer Centric Organization) (Simon, VAn Den DriesT, \& Wilms, 2016). The intense and dynamic competition in the airport industry requires AP II to have proper airport service standardization through the interaction of passenger activities in building the attraction of the extraordinary airport (Ridhwanullah, 2016). Therefore, it manages to provide a pleasant passenger experience in order to leave a positive memory impression on all airport customers as a competitive advantage. (Popovic, Kraal, \& Kirk, 2010) describe airport passenger experience as "the activities / activities and interactions that passengers pass through inside an airport terminal". According to the International Air Transport Association, abbreviated as (Turner, 2010), passenger activities consist of processing and non-processing activities as indicators of measuring the optimization of airport service performance in increasing airport customer satisfaction (Majid, 2020). Terminal 1 Soekarno-Hatta Airport is a terminal with a special class of service for low-cost carriers (low-cost carrier terminal) for domestic flight routes. Currently, Terminal 1-BSH only serves Lion Air airlines, consisting of domestic passengers and foreign tourists on leisure and business trips. According to (Wiredja, Popovic, \& Blackler, 2019) These two types of passengers will pass a series of service processing and non-processing activities in the departure, transit, 
and arrival areas according to IATA standards, which is shown in Figure 2

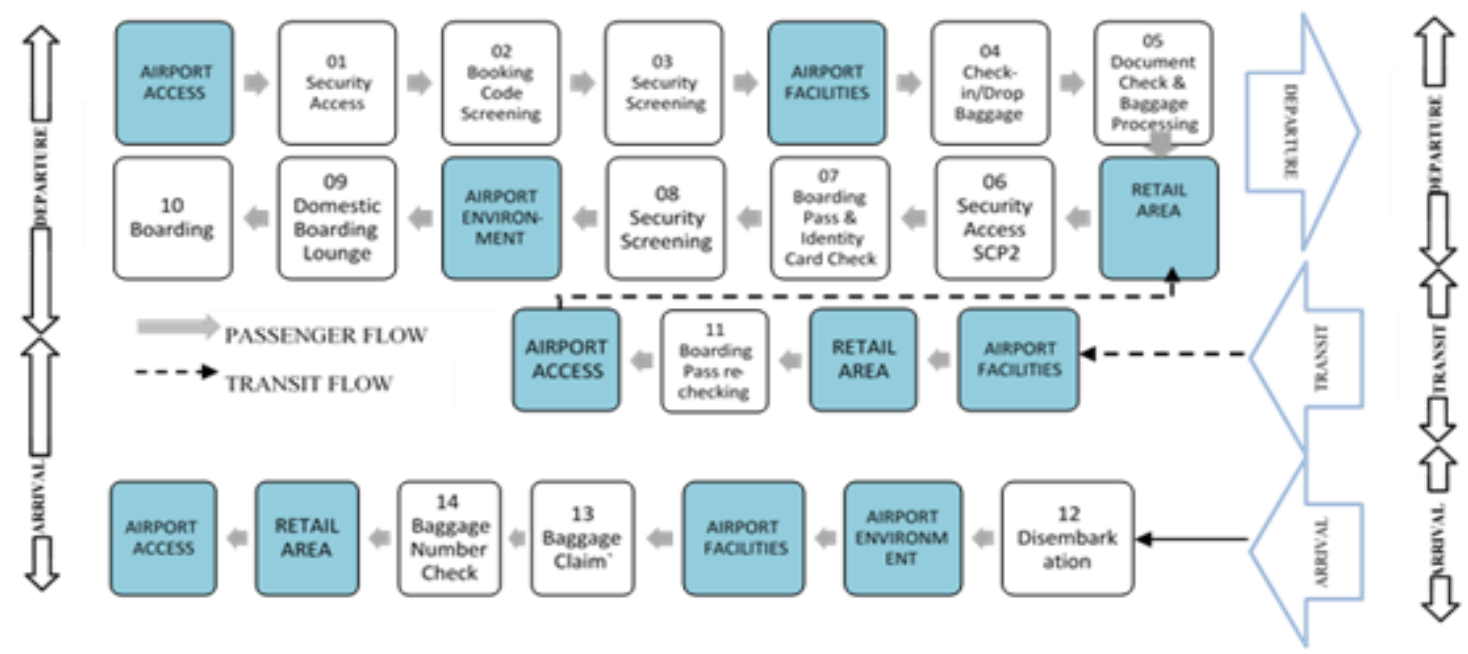

Source: IATA, ADRM $11^{\text {th }}$ Edition, 2019

Terminal 1-BSH as an LCC terminal has experienced an increase in passenger movement which is directly proportional to the number of passenger dissatisfaction each year. Terminal 1 manager have made efforts to improve services, but there are still many service attributes that need attention as a reflection of the gap between service performance and airport customer expectations of the two service processes. Passenger dissatisfaction data consists of a collection of passenger's bad experiences, suggestions, and major recommendations which have been summarized in Table 1.

Table 1

Service Attributes of Terminal 1 Passenger Dissatisfaction - BSH

\begin{tabular}{|c|c|c|c|c|c|}
\hline Atribut Pelayanan & 2015 & 2016 & 2017 & 2018 & 2019 \\
\hline \multicolumn{6}{|l|}{ Bandara } \\
\hline Check-in & $\square$ 15.2\% & 16.6\% & & & $31.3 \%$ \\
\hline Security & $10.2 \%$ & & $16.8 \%$ & $20.5 \%$ & \\
\hline Airport Facilities & $39.1 \%$ & $59.2 \%$ & $34.7 \%$ & $50.4 \%$ & $42.4 \%$ \\
\hline Baggage Claim & $12.7 \%$ & 11.5\% & 17.3\% & & $26.3 \%$ \\
\hline Retail Area & $22.8 \%$ & & $18.4 \%$ & $19.3 \%$ & \\
\hline Airport Access & & $22.3 \%$ & & & \\
\hline Airport Environment & & & $12.8 \%$ & & \\
\hline
\end{tabular}

Source: Survey CSI, ASQ, SKYTRAX 2015 - 2019 year's report

Table 1 explains that the services that have been implemented have not been able to guarantee the optimization of airport service performance. The purpose of this research is to help the management of Terminal 1 - BSH to assess the decreased service attributes and to redefine products and services in accordance with the perspective approach of airport passengers at LCC terminals. Therefore, airport service performance is more optimal (Nasution-Patrick, de Yong, Lukito, \& Aziz, 2016). In addition, in the end it is able to provide reliable, consistent and enjoyable experience for passenger that exceeds the expectations of airport passengers according to the Company's mission. The objectives of this study are: 
1. To identify the processing of passenger activity services at Terminal $1-\mathrm{BSH}$;

2. To find out the right type of passenger activity service that will affect the optimization of airport service performance at Terminal 1 - BSH;

To develop a passenger activity service model to optimize the performance of Terminal 1 - BSH airport.

\section{Research Methods}

Case studies in a research are a way to understand the discussed problems by expanding knowledge through the previous discussion (Kurniawan, Sebhatu, \& Davoudi, 2017). A case study is a summary of a discussion document conducted intensively on a particular organization or symptom to be reported and provides a critical assessment of the case (Freeman, Baumann, Fisher, Blythe, \& Akhtar-Danesh, 2012). This case study research was conducted at Terminal 1 Soekarno-Hatta Airport, which is the LCC Terminal with the highest number of flight and passenger movements. Therefore, it can determine the development of a service model to improve the airport passenger experience which will be adjusted to the types of business and leisure passengers (ACRP Report 157, 2016). The target population of this study were all passengers on the airline Terminal 1 Soekarno-Hatta Airport. Determination of the number of objects (samples) uses a random sampling technique with the Slovin formula in order to obtain a total sample of 100 people (Amir \& Ralph, 2018) . The research instrument test is carried out as a tool to measure the observed phenomenon or problem and usually uses correlation techniques through validity and reliability tests (Sugiyono, 2017) The validity test shows the extent to which a measuring instrument is suitable to measure what you want to measure. The basis for decision making is that if the value of $r$ count is greater than $r$ table, then each indicator (statement) is declared valid and vice versa if the value of $r$ count is less than $r$ table, then each indicator (statement) is declared invalid. The value of $r$ table depends on the number of samples, the number of samples in this study was 100 respondents, then the value of $r$ table $=0.195$. Testing the validity of these two measurements by using SPSS version 25.0 is shown in Table 6 (Ghozali, 2016)

Table 2

Test of Perceived and Importance Validity

\begin{tabular}{|l|r|r|}
\hline \multicolumn{3}{|c|}{ Validity Statistics } \\
\hline Total Score & PERCEIVED & \multicolumn{1}{|c|}{ IMPORTANCE } \\
\hline Pearson Correlation & 0,797 & 0,827 \\
\hline Sig. (2-tailed) & 0,000 & 0,000 \\
\hline N & 100 & 100 \\
\hline ** Correlation is significant at the 0.01 level (2-tailed) \\
\hline
\end{tabular}

Source: Primary Data Results, processed in 2020

In Table 2, it can be seen that the value of Perceived and Importance $\geq 0.195$, then all indicators in the questionnaire are declared valid. Meanwhile, the reliability test is to determine the level of consistency and reliability of the questionnaire in measuring the research variables. Cronbach's Alpha coefficient $(\alpha)$ is the reliability coefficient of statistical data instruments with a coefficient value greater than or equal to 0.60 . 
The data that has been collected and has been tested for validity and reliability is continued with the analysis of the House of Quality (HoQ) matrix data processing (Ramírez, Cisternas, \& Kraslawski, 2017). HoQ input data comes from the processing of Quality Function Deployment (QFD) data analysis. Furthermore, the results of the priority order of service improvements come from the Analytic Hierarchy Process (AHP) method. Intended to capture customer desires and to see service attributes that must be prioritized as the company's basis in making decisions to fulfill needs, the expectations of airport passengers will be contained in the design of the Airport Passenger Experience Model for the LCC Terminal. The following are the stages of the analysis of this research, as follows:

1. Analysis of Customer Requirements (CR) service attributes is through the stages of the Quality Function Deployment (QFD) method from the results of the first questionnaire distribution. This stage is carried out with the aim of knowing the real performance conditions of passenger activity service processing, consisting the service attributes of processing and non-processing activities;

2. Analysis of the Analytic Hierarchy Process (AHP) is obtained from the results of distributing the second questionnaire. This stage will get a priority order (ranking) from the assessment of processing and non-processing variables with a consistency level of assessment. There are 3 stages of the AHP method research, namely:

a. Identification and arrangement of the three-level AHP hierarchical structure consisting of goals, criteria, and sub-criteria. These criteria and sub-criteria are an expression of the level of importance of airport passengers as questionnaire data;

b. AHP weight and priority quantification - pairwise comparisons are the data from the distributed questionnaires which are processed according to the AHP method stages with the Expert Choice-11 software tool. The results of questionnaire data processing with AHP are in the form of Relative Importance (RI) values. Therefore, the consistency value of the assessment, namely CR (Consistency Ratio), is stated to be consistent if $\mathrm{CR}<0.1$ and the weighted value and priority of the results are.

c. Determination of Service Attribute Importance Level is the weighted value and priority results which become an input to Customer Requirements in the House of Quality (HoQ) development stage;

3. Formulation of a House of Quality (HoQ) completes the performance of service attributes that still have a high gap as an effort to develop and improve service quality at every touch point of airport passenger activities. HoQ process stages include Customer Needs (What's matrix), Technical Response (How's matrix), Relationship between Customer Needs and Technical Response, Technical Correlation, and Planning Matrix and Technical Response Weight (Technical Matrix);

4. The design of a service development model for Terminal 1 of Soekarno-Hatta Airport will be adjusted to the type of domestic airport passenger from the combination of the results of QFD analysis, AHP analysis and HoQ analysis, namely the Airport Passenger Experience Model as a program template for improving the service experience of LCC Terminal airport passengers 
Airport Passenger Experience Model for Terminal Low-Cost Carrier (Study Case at Terminal 1 Soekarno-Hatta International Airport)

\section{Results and Discussions}

1. Gap Analysis using QFD Method

The analysis of the QFD method describes the voice of Terminal 1-BSH passengers from the results of the distribution of the first questionnaire that was randomly carried out in the departure, transit, and arrival areas with the category of assessing the importance of the services offered (Importance) and the level of perceived service (Perceived). The results of the difference between Perceived and Importance are shown in Figure 2

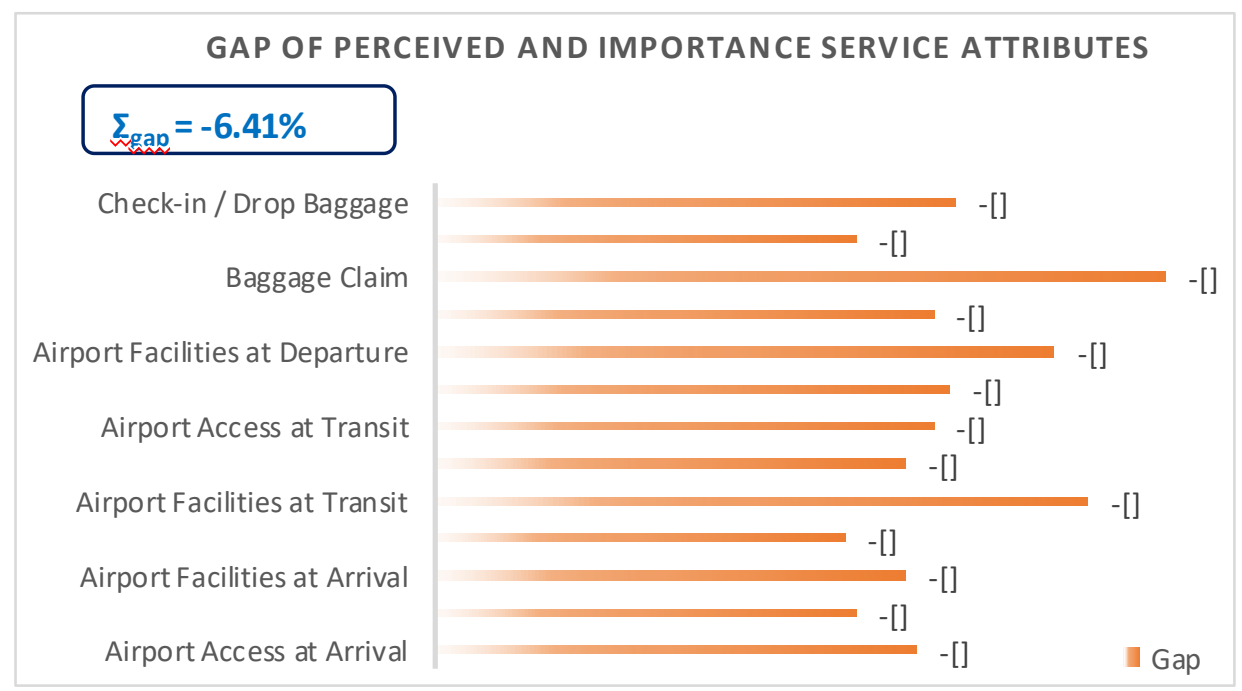

Figure 2. Gap Analysis between Perceived vs Importance

Source: Primary Data Results, processed in 2020)

In Figure 5, it shows the results of the gap analysis with the following details:

a. The average satisfaction threshold between Perceived and Importance is $6.41 \%$. In the sense that if any service attribute has a gap value greater than the threshold, then there are problems that result in a decreased airport service quality which cause the airport passengers feel dissatisfied or disappointed.

b. 20 service attributes have a negative gap value or exceed the average satisfaction threshold, indicating a decrease in service attribute performance;

c. The proportion of passengers who feel dissatisfied in the departure service area is higher than in the arrival area.

2. Priority Sequence Analysis of Passenger Interest Level using AHP Method

Identification of goals, criteria, and sub-criteria in the AHP method analysis is to obtain a priority order (ranking) of the variable assessment of processing and nonprocessing activities with a consistency level of assessment as a priority basis for making decision of improvements and improving the quality of airport services. The following is the AHP hierarchical structure for improving the service of passenger activities in Terminal 1-BSH, shown in Figure 3 


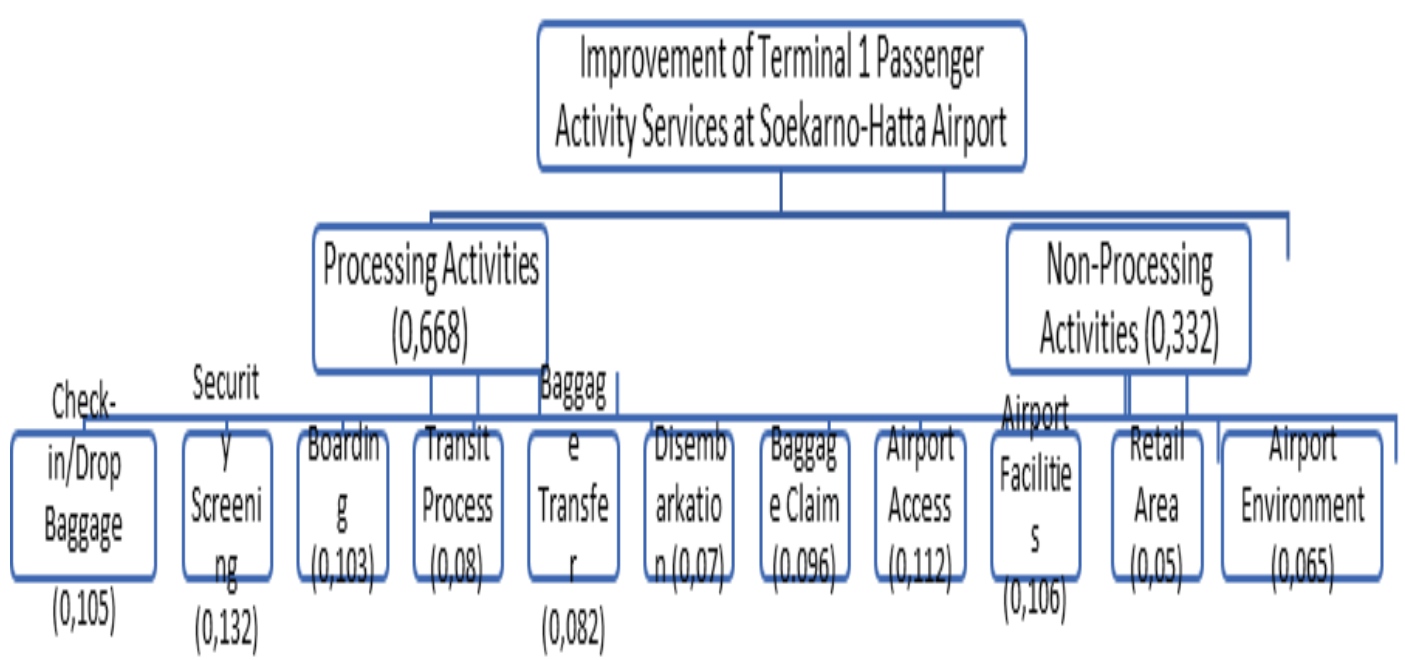

Source: Primary Data Results, processed in 2020

Figure 3 shows the results of the second questionnaire distribution (pairwise comparisons) through the help of Expert Choice software version 11.0. The weighting of the processing activities criteria is 0.668 and the criterion for nonprocessing activities is 0.332 with the average value of the final weighting of each sub-criterion (element), and Consistency Ratio $(\mathrm{CR})=0.00881$ or $<0.1$. Therefore, the pairwise comparison matrix results can be stated as consistent. Of all the weight of the final service sub-criteria (elements) in the AHP hierarchical structure, it can be determined that the priority ranking (ranking) is determined based on the weighted average value sorted from the highest to the lowest value, which is shown in Figure 4.

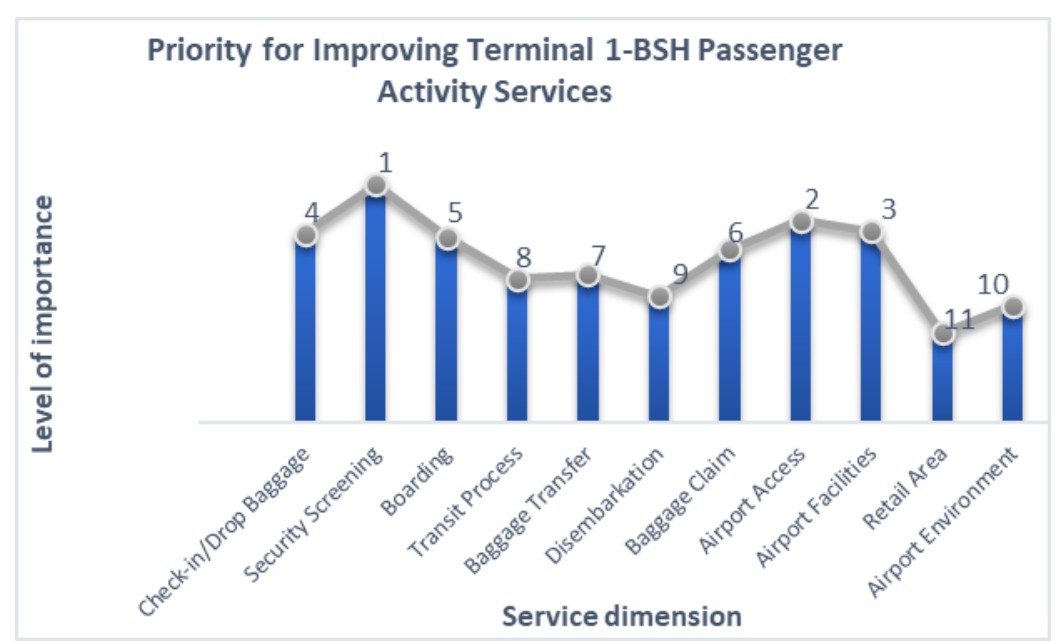

Figure 4

Priority Level of Interest for Terminal 1 Passengers - BSH

Source: Primary Data Results, processed in 2020 
In Figure 4, there are 5 (five) highest priority sequences based on the level of interest of Terminal 1-BSH passengers, including Security Screening $=13.2 \%$, Airport Access $=11.2 \%$, Airport Facilities $=10.6 \%$, Check-in $/$ Drop Baggage $=$ $10.5 \%$ and Boarding $=10.3 \%$. By knowing the five highest priorities based on the level of interest of airport passengers, it becomes a reference in determining the technical response as a follow-up to improvement or service development to improve passenger activity services which will affect the optimization of the service performance of Terminal 1 Soekarno-Hatta Airport.

3. Proposal for Improvement of Service Quality for Passenger Activities by using House of Quality (HoQ) Analysis

The final stage is the result of the compilation of the House of Quality. From the results of the gap analysis (QFD method) and the five highest priority rankings for the level of passenger interest (AHP method), 17 technical responses were obtained according to the characteristics of the airport terminal based on the management capability of Terminal 1-BSH (How's matrix). The responses are presented in Table 3.

Table 3

Technical Responses from Gap Analysis

\begin{tabular}{|c|c|c|c|}
\hline Category & Service Attributes Element & Technical Response & Remark \\
\hline \multirow{4}{*}{$\begin{array}{l}\text { The } \\
\text { highest } \\
\text { AHP } \\
\text { Priority } \\
\text { Rating } \\
\text { (Rank) }\end{array}$} & $\begin{array}{l}\text { Security Screening: } \\
\text { Queue waiting time during the } \\
\text { inspection process }\end{array}$ & $\begin{array}{l}\text { 1. Distinguishing the screening entry } \\
\text { according to the type of passenger with } \\
\text { the same inspection SOP standard }\end{array}$ & $\begin{array}{l}\text { Service } \\
\text { Developme } \\
\text { nt }\end{array}$ \\
\hline & $\begin{array}{l}\text { Airport Access: } \\
\text { a. The availability of various } \\
\text { public transportation options } \\
\text { from and to the airport }\end{array}$ & $\begin{array}{l}\text { 2. Providing digital public transportation } \\
\text { schedule and route information services }\end{array}$ & $\begin{array}{l}\text { Additional } \\
\text { Services }\end{array}$ \\
\hline & $\begin{array}{l}\text { b. The waiting time for public } \\
\text { transport queues should not be } \\
\text { more than } 15 \text { minutes (such } \\
\text { as: airport taxis and online } \\
\text { transportation) }\end{array}$ & $\begin{array}{l}\text { 3. Affording smart taxi facility in line } \\
\text { with airport app }\end{array}$ & $\begin{array}{l}\text { Service } \\
\text { Developme } \\
\text { nt }\end{array}$ \\
\hline & $\begin{array}{l}\text { c. The availability of parking } \\
\text { space and ease of finding a } \\
\text { parking space }\end{array}$ & $\begin{array}{l}\text { 4. Providing premium parking products } \\
\text { services (such as: parking space, Valet } \\
\text { \& reserved, parking lounge, washing } \\
\text { car, service station, online payment } \\
\text { system }\end{array}$ & $\begin{array}{l}\text { Additional } \\
\text { Services }\end{array}$ \\
\hline
\end{tabular}

\section{Airport Facilities:}

a. The availability of Terminal Comfort area options: TV Entertainment, Gaming, rest area and children's play facilities
5. Arranging addition of co-working space / business center facilities (short meeting \& print documents)

6. Placing addition of prepaid sports area facilities (such as: yoga and fitness)

Providing online communication channels (such as: Feedback, Live Chat, newsletter, email)

The availability of internet facilities, WIFI and free charging
Increasing the duration and WIFI access points as well as free power outlets
Service

Developme nt

Service Developme nt

Service

Developme nt

Improveme nt Service 


\begin{tabular}{|c|c|c|c|}
\hline \multirow[t]{6}{*}{ Category } & Service Attributes Element & Technical Response & Remark \\
\hline & with a stable connection & & \\
\hline & $\begin{array}{l}\text { The availability of bank / ATM / } \\
\text { money changer facilities }\end{array}$ & $\begin{array}{l}\text { Adding an ATM center and money } \\
\text { changer in the arrival hall area }\end{array}$ & $\begin{array}{l}\text { Additional } \\
\text { site point }\end{array}$ \\
\hline & $\begin{array}{l}\text { Check-in / Drop Baggage: } \\
\text { The waiting time for the check-in } \\
\text { / drop baggage queue should not } \\
\text { be more than } 15 \text { minutes }\end{array}$ & $\begin{array}{l}\text { Distinguishing check-in/baggage drop } \\
\text { counters according to passenger types }\end{array}$ & $\begin{array}{l}\text { Improveme } \\
\mathrm{nt} \text { or } \\
\text { Modificati } \\
\text { on Service }\end{array}$ \\
\hline & & Providing excess baggage service & $\begin{array}{l}\text { Service } \\
\text { Developme } \\
\mathrm{nt}\end{array}$ \\
\hline & & $\begin{array}{l}\text { Providing express package delivery } \\
\text { services }\end{array}$ & $\begin{array}{l}\text { Additional } \\
\text { Services }\end{array}$ \\
\hline \multirow[t]{5}{*}{$\begin{array}{l}\text { The } \\
\text { highest } \\
\text { service } \\
\text { quality } \\
\text { gap }\end{array}$} & $\begin{array}{l}\text { Boarding: } \\
\text { Easy and efficient boarding } \\
\text { procedure }\end{array}$ & $\begin{array}{l}\text { Adding inline self-boarding services with } \\
\text { airport apps }\end{array}$ & $\begin{array}{l}\text { Service } \\
\text { Developme } \\
\text { nt }\end{array}$ \\
\hline & $\begin{array}{l}\text { Baggage Claim: } \\
\text { Baggage delivery speed should } \\
\text { not exceed } 15 \text { minutes }\end{array}$ & $\begin{array}{l}\text { Arranging baggage tracking inline facility } \\
\text { with airport apps }\end{array}$ & $\begin{array}{l}\text { Service } \\
\text { Developme } \\
\text { nt }\end{array}$ \\
\hline & $\begin{array}{l}\text { Retail Area: } \\
\text { Availability of retail shop } \\
\text { variants and cafes / restaurants in }\end{array}$ & $\begin{array}{l}\text { Providing tourist information center } \\
\text { services }\end{array}$ & $\begin{array}{l}\text { Additional } \\
\text { Services }\end{array}$ \\
\hline & the departure area & $\begin{array}{l}\text { Holding a seasonal event or cultural } \\
\text { exhibition (such as: Live local tradition } \\
\text { music, local food, art \& tradition ethic) }\end{array}$ & $\begin{array}{l}\text { Service } \\
\text { Developme } \\
\text { nt }\end{array}$ \\
\hline & $\begin{array}{l}\text { Availability of local SIM card } \\
\text { and locker rental }\end{array}$ & $\begin{array}{l}\text { Providing local prepaid SIM e-kiosk and } \\
\text { smart locker rent facilities }\end{array}$ & $\begin{array}{l}\text { Additional } \\
\text { Services }\end{array}$ \\
\hline
\end{tabular}

Source: Primary Data Results, processed in 2020

Table 3 shows 17 technical responses in the form of adding or developing services as an effort to help airport management and to improve service quality at each touch point of Terminal 1-BSH passenger type activities. The results of a series of HoQ process stages with the help of Edraw Max software (attached to the Appendix) obtained the 5 highest priorities of service development from 17 Needs \& Importance technical response rankings. These results are shown in Figure 9. 


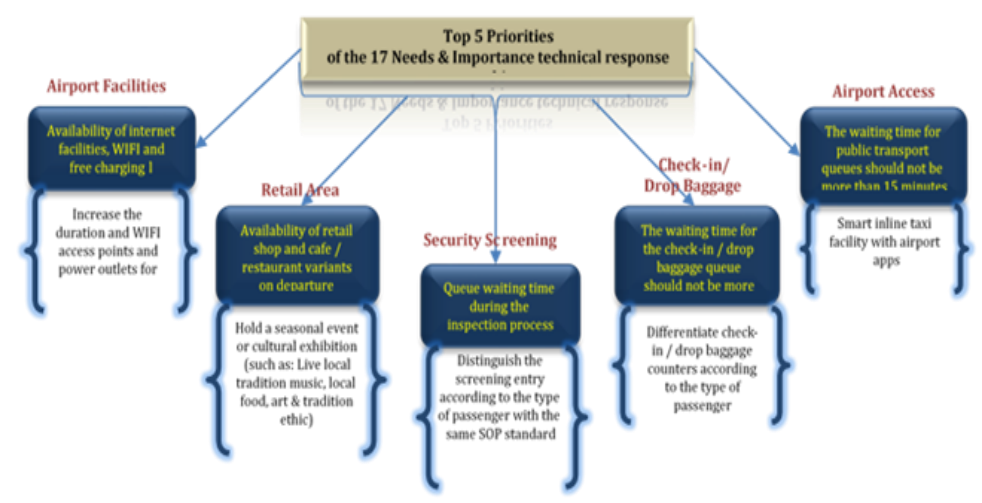

Figure 5. Highest Priority for Service Improvement and Improvement of Passenger Activities Services Terminal 1 - BSH Source: Primary Data Results, processed in 2020

Based on the performance of airport services (KPI Airport, IATA), the needs (Perceived) and the level of importance (Importance) of airport passengers which are benchmarks must be met by Terminal 1 management. These are shown by starting from the first sequence as a priority program for service improvement and development that will be adjusted to their capabilities, companies, and the characteristics of the airport itself to improve Terminal 1-BSH passenger activity services. According to Lou Cohen (year) in the book Quality Function Deployment, service attributes that rank 1 to 5 are a priority that must be applied first. The five highest priority programs are in accordance with Terminal $1-\mathrm{BSH}$ passenger types to solve service attribute performance problems in the What's matrix. The services are namely increasing the duration and WIFI access points as well as free power outlets by $12.57 \%$, organizing seasonal events or cultural exhibitions (such as Live local tradition music, local foods, art \& tradition ethic) of $12.33 \%$, distinguishing the screening entry according to the type of passenger with the same SOP standard of $10.02 \%$, distinguishing check-in / baggage drop counters according to passenger type $9.67 \%$, and arranging smart inline taxi facility with airport app by $9.14 \%$ (Cohen, 1995).

4. Airport Passenger Experience Model Design for improving LCC Terminal services

Based on the 20 Gap identification results of passenger needs through the QFD method (Needs) (Fajri, 2020), 5 Priority Levels of interest for airport passengers through the AHP (Importance) method, and 17 Needs \& Importance technical responses through HoQ analysis, it can be designed to be a development model for passenger activity services at Terminal 1 Soekarno - Hatta Airport. This design is the Airport Passenger Experience Model for the LCC Terminal. This model is also based on the concept of airport passenger experience management from the overall assessment of airport passengers, evaluation of Terminal 1 management, and innovation of outside airports (ACRP 157, 2016) as a strategy for optimizing airport service performance, which is shown in Figure 10. 
Figure 6 Terminal 1 - BSH Airport Passenger Experience Model

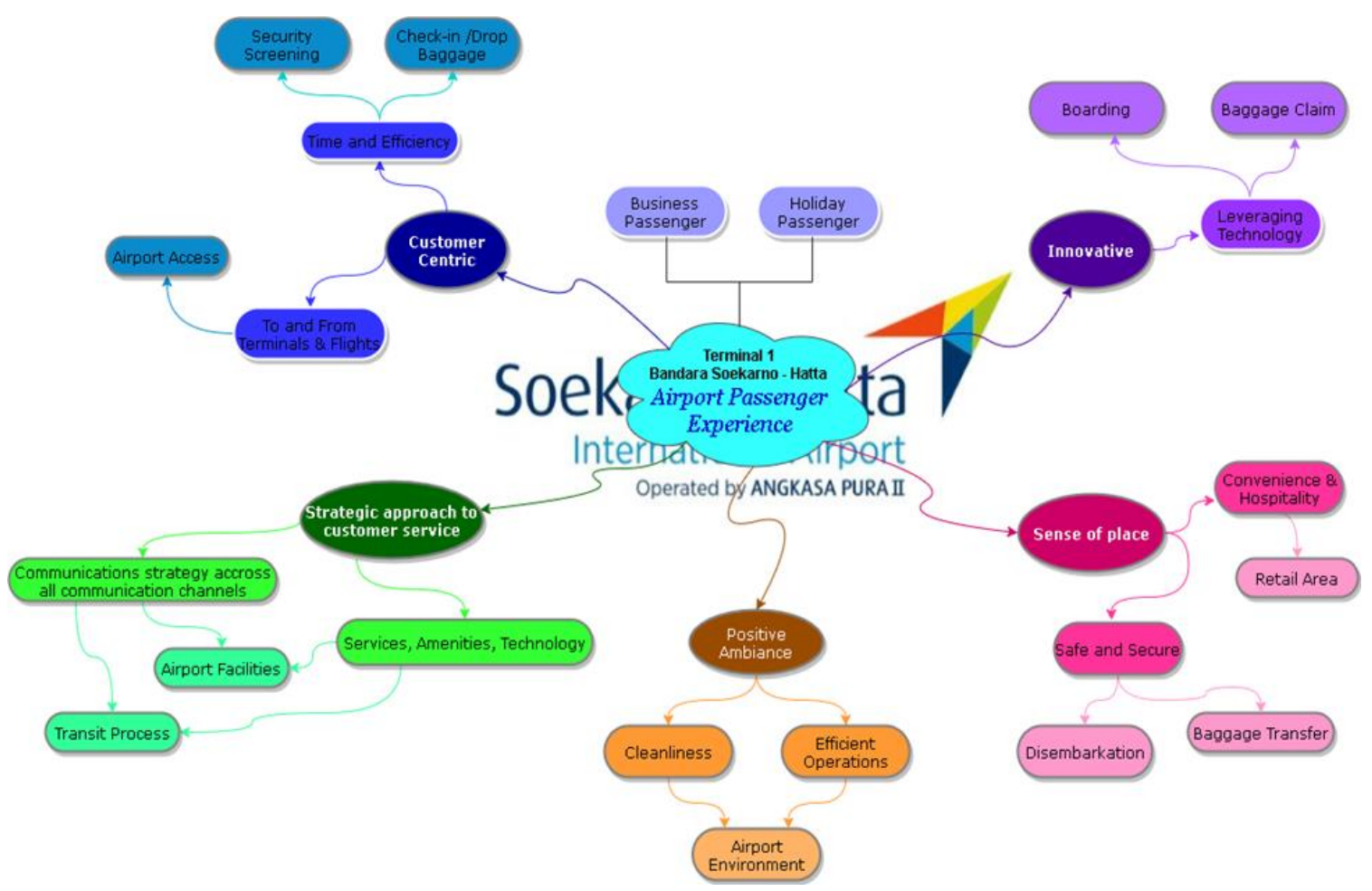

Source: Primary Data Results, processed in 2020

In Figure 6, the Airport Passenger Experience Model for the business and leisure passenger types at Terminal 1 Soekarno-Hatta Airport is designed from five priority programs called the Panca Program, including:

a. Customer Centric focuses on two things which are time and efficiency to improve the security screening and check-in / drop baggage services and to and from terminals and flights to develop airport access services;

b. Strategic Approach to Customer Service focuses on communications strategy across all communication channels and services, amenities, and technology. This program is for the development of airport facilities and transit process services;

c. Innovative focuses on leveraging technology to improve services on boarding and baggage claim;

d. Sense of Place focuses on convenience and hospitality for the development of retail area services and on safety and security for the disembarkation and baggage transfer services; and last

e. Positive Ambiance focuses on cleanliness and efficient operations for Airport Environment services.

Each of the development and improvement of Panca Program services in the Airport Passenger Experience Model for the types of business and leisure passengers at Terminal 1 Soekarno-Hatta Airport are described in Table 4. 
Airport Passenger Experience Model for Terminal Low-Cost Carrier (Study Case at Terminal 1 Soekarno-Hatta International Airport)

Table 4

Airport Passenger Experience Model (AIPEX Model) of Terminal 1 Soekarno - Hatta Airport

\begin{tabular}{|c|c|c|c|c|c|c|c|c|}
\hline $\begin{array}{l}\text { AIPEX model } \\
\text { Characteristics }\end{array}$ & Parameter & Element & \multicolumn{2}{|c|}{$\begin{array}{c}\text { Service } \\
\text { Attributes } \\
\text { Current } \\
\text { Condition }\end{array}$} & \multicolumn{2}{|c|}{$\begin{array}{c}\text { Service } \\
\text { Attributes } \\
\text { Development }\end{array}$} & $\begin{array}{c}\text { Passenger } \\
\text { Targeting } \\
\text { Business }\end{array}$ & $\begin{array}{c}\text { Goals } \\
\text { Strong build } \\
\text { up towards } \\
\text { the "Airport } \\
\text { Brand } \\
\text { Experience" } \\
\text { Leisure } \\
\end{array}$ \\
\hline $\begin{array}{l}\text { Customer } \\
\text { Centric }\end{array}$ & $\begin{array}{l}\text { Time and } \\
\text { Efficiency }\end{array}$ & $\begin{array}{l}\text { Check-in / } \\
\text { Drop } \\
\text { Baggage }\end{array}$ & $\begin{array}{l}\text { Queue } \\
\text { waiting } \\
\text { time, the } \\
\text { check- } \\
\text { in/drop } \\
\text { baggage } \\
\text { process, } \\
\text { and the } \\
\text { attitude of } \\
\text { the check- } \\
\text { in clerk }\end{array}$ & $\begin{array}{l}1 . \\
2 . \\
2 .\end{array}$ & $\begin{array}{l}\text { Distin } \\
\text { guishi } \\
\text { ng } \\
\text { check- } \\
\text { in/bag } \\
\text { gage } \\
\text { drop } \\
\text { counte } \\
\text { rs } \\
\text { accord } \\
\text { ing to } \\
\text { passen } \\
\text { ger } \\
\text { types } \\
\text { Provid } \\
\text { ing } \\
\text { excess } \\
\text { bagga } \\
\text { ge } \\
\text { servic } \\
\text { e } \\
\text { Provid } \\
\text { ing } \\
\text { expres } \\
\text { s } \\
\text { packa } \\
\text { ge } \\
\text { delive } \\
\text { ry } \\
\text { servic } \\
\text { es }\end{array}$ & $\sqrt{ }$ & $\sqrt{ }$ & $\begin{array}{l}\text { 1. Reduc } \\
\text { ing } \\
\text { queue } \\
\text { length } \\
\text { satura } \\
\text { tion } \\
\text { and } \\
\text { time } \\
\text { efficie } \\
\text { ncy } \\
\text { Provi } \\
\text { ding } \\
\text { conve } \\
\text { nience } \\
\text { and } \\
\text { comfo } \\
\text { rt and } \\
\text { impro } \\
\text { ve } \\
\text { servic } \\
\text { e } \\
\text { excell } \\
\text { ence } \\
\text { (servi } \\
\text { ce } \\
\text { excell } \\
\text { ence) }\end{array}$ \\
\hline & & $\begin{array}{l}\text { Security } \\
\text { Screening }\end{array}$ & $\begin{array}{l}\text { Attitude } \\
\text { of } \\
\text { security } \\
\text { officers, } \\
\text { waiting } \\
\text { time } \\
\text { queues, } \\
\text { feeling } \\
\text { safe and } \\
\text { secure }\end{array}$ & $\begin{array}{l}\text { Dis } \\
\text { hin } \\
\text { scr } \\
\text { ent } \\
\text { acc } \\
\text { to t } \\
\text { typ } \\
\text { pas } \\
\text { wit } \\
\text { san } \\
\text { ins } \\
\text { SO }\end{array}$ & $\begin{array}{l}\text { tinguis } \\
\mathrm{g} \text { the } \\
\text { eening } \\
\text { ry } \\
\text { ording } \\
\text { he } \\
\text { e of } \\
\text { senger } \\
\text { h the } \\
\text { ne } \\
\text { pection } \\
\text { P }\end{array}$ & $\sqrt{ }$ & $\sqrt{ }$ & $\begin{array}{l}\text { Reducing } \\
\text { queue } \\
\text { length, } \\
\text { burnout } \\
\text { and time } \\
\text { efficiency } \\
\text { for } \\
\text { business } \\
\text { passenger } \\
\text { s }\end{array}$ \\
\hline & $\begin{array}{l}\text { To and } \\
\text { From } \\
\text { Terminals } \\
\text { \& Flights }\end{array}$ & $\begin{array}{l}\text { Airport } \\
\text { Access }\end{array}$ & $\begin{array}{l}\text { The } \\
\text { choice of } \\
\text { various } \\
\text { public } \\
\text { transporta } \\
\text { tion } \\
\text { options } \\
\text { from and } \\
\text { to the } \\
\text { airport, }\end{array}$ & 1. & $\begin{array}{l}\text { Provid } \\
\text { ing } \\
\text { digital } \\
\text { public } \\
\text { transp } \\
\text { ortatio } \\
\mathrm{n} \\
\text { sched } \\
\text { ule } \\
\text { and }\end{array}$ & $\sqrt{ }$ & $\sqrt{ }$ & $\begin{array}{l}\text { 1. Provi } \\
\text { ding } \\
\text { new } \\
\text { servic } \\
\text { es } \\
\text { thorou } \\
\text { gh } \\
\text { infor } \\
\text { matio } \\
\mathrm{n}\end{array}$ \\
\hline
\end{tabular}


Mora Yolanda Sagala, Ina Primiana Sagir, Iman Chaerudin

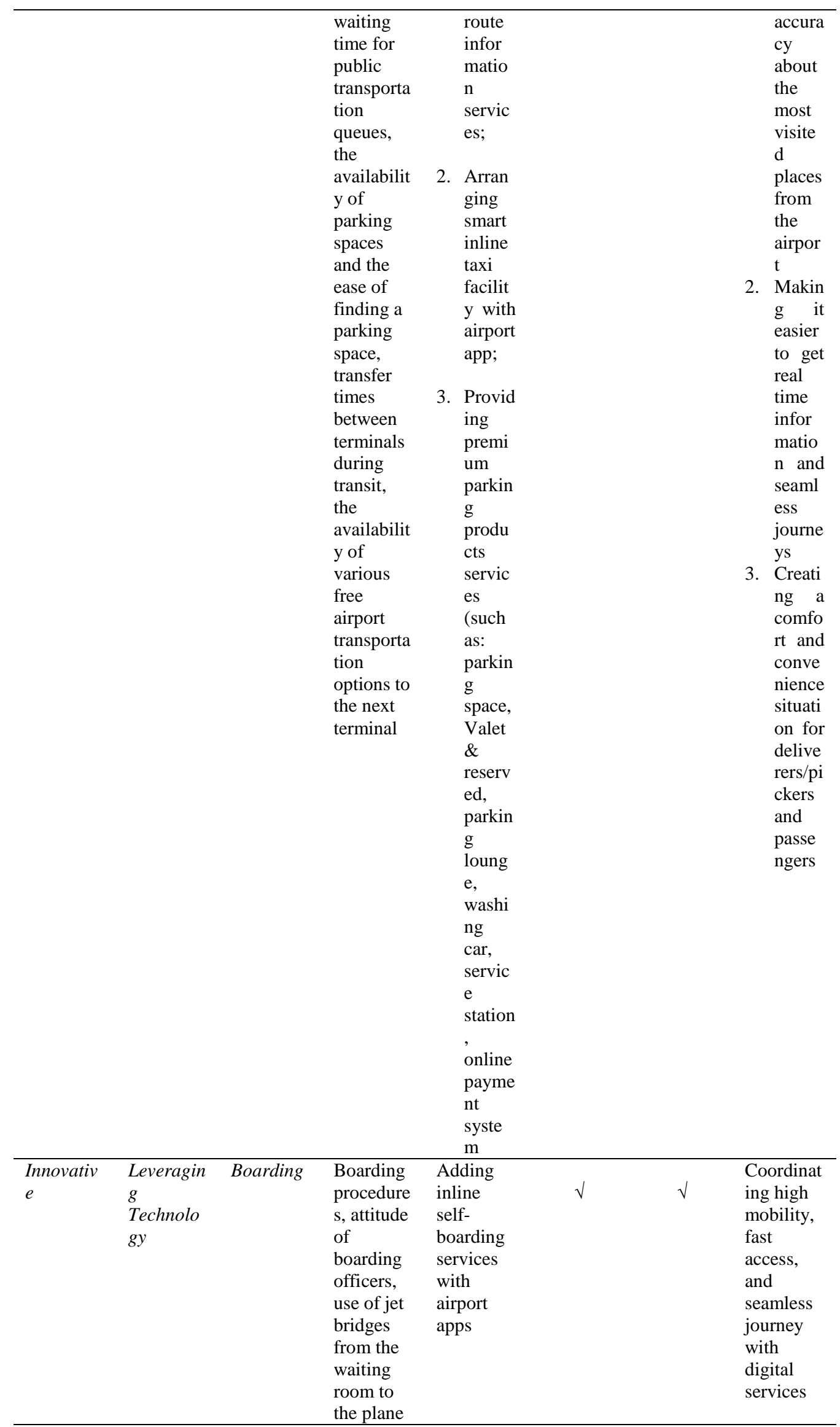


Airport Passenger Experience Model for Terminal Low-Cost Carrier (Study Case at Terminal 1 Soekarno-Hatta International Airport)

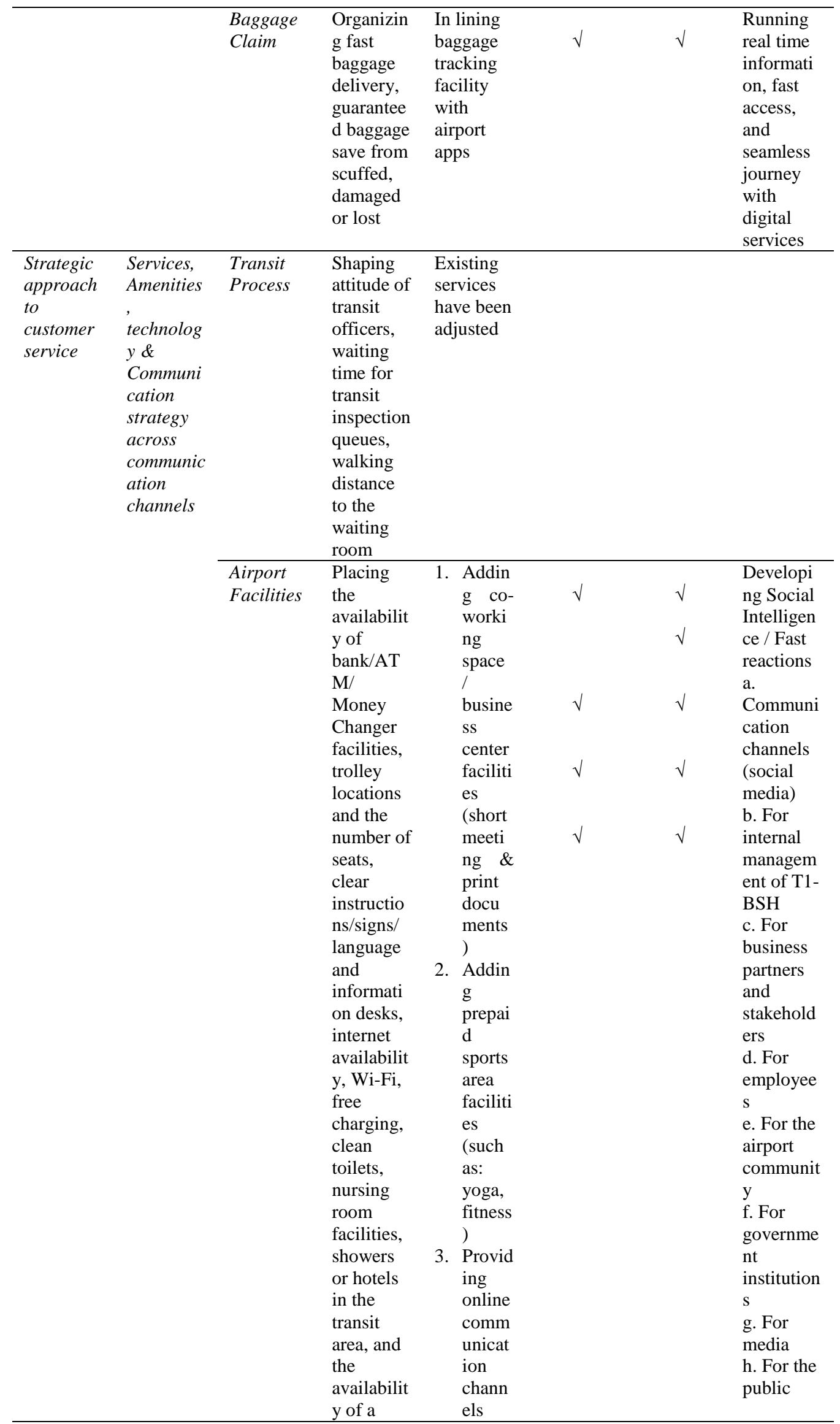


Mora Yolanda Sagala, Ina Primiana Sagir, Iman Chaerudin

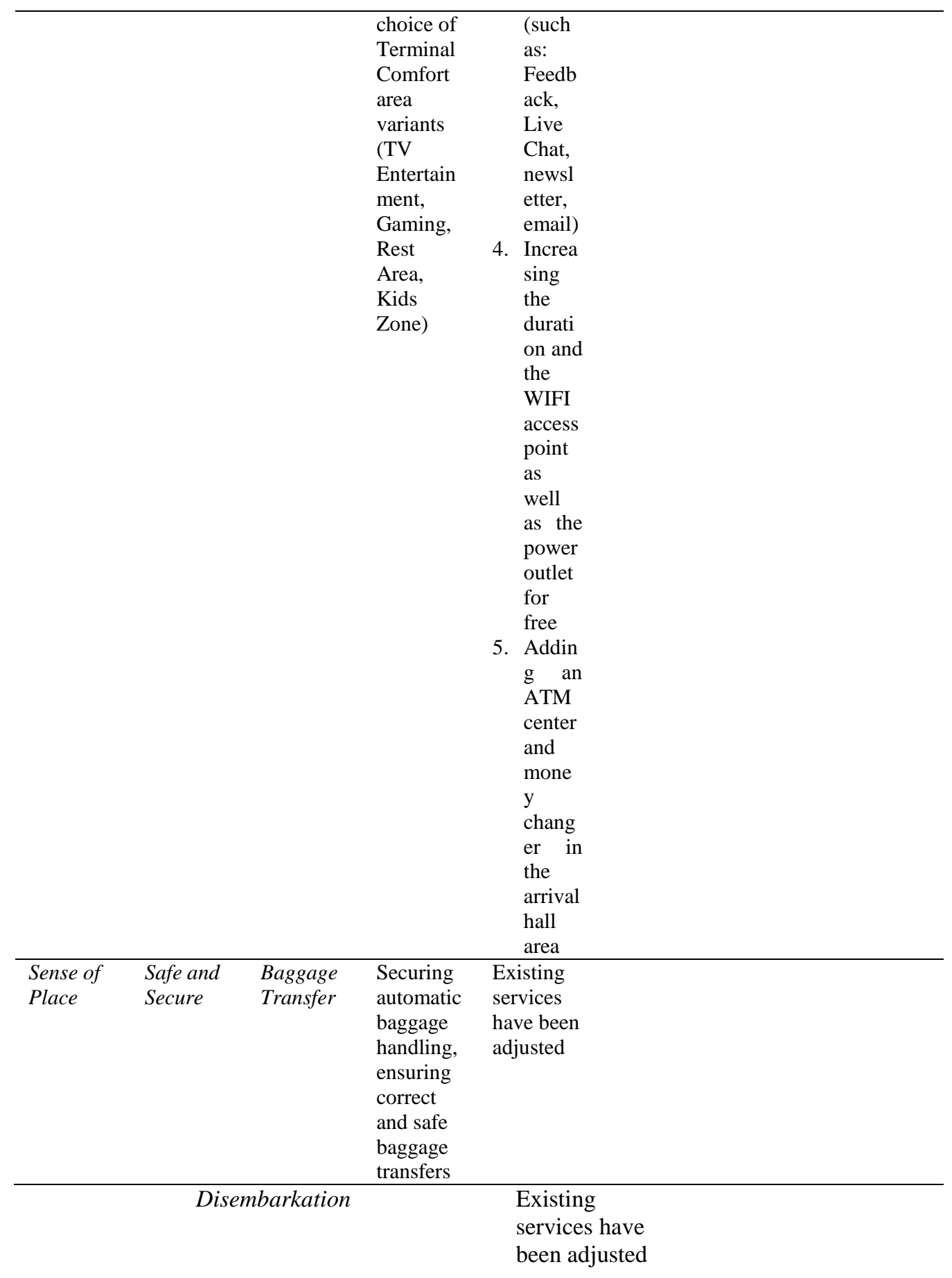

\begin{tabular}{|c|c|c|c|c|c|c|}
\hline $\begin{array}{l}\text { Convenience Retail Area } \\
\& \\
\text { Hospitality }\end{array}$ & $\begin{array}{l}\text { Using a jet } \\
\text { bridge from the } \\
\text { plane to the } \\
\text { terminal } \\
\text { building, } \\
\text { walking } \\
\text { distance to } \\
\text { baggage claim }\end{array}$ & 1. & $\begin{array}{l}\text { Providing } \\
\text { tourist } \\
\text { informati } \\
\text { on center } \\
\text { services } \\
\text { Holding } \\
\text { a } \\
\text { seasonal } \\
\text { event or } \\
\text { cultural }\end{array}$ & $\sqrt{ }$ & $\sqrt{ }$ & $\begin{array}{l}\text { 1. Obtaining } \\
\text { city-hub } \\
\text { information } \\
\text { easily } \\
\text { (accessibilit } \\
\text { y to and } \\
\text { from the } \\
\text { airport), } \\
\text { especially } \\
\text { for leisure }\end{array}$ \\
\hline
\end{tabular}




\begin{tabular}{|c|c|c|c|c|c|}
\hline & & & & $\begin{array}{l}\text { exhibitio } \\
\mathrm{n} \quad \text { (such } \\
\text { as: Live } \\
\text { local } \\
\text { tradition } \\
\text { music, } \\
\text { local } \\
\text { food, art } \\
\text { \& } \\
\text { tradition } \\
\text { ethic) } \\
\text { Providing } \\
\text { local } \\
\text { prepaid } \\
\text { SIM e- } \\
\text { kiosk and } \\
\text { smart } \\
\text { locker } \\
\text { rent } \\
\text { facilities }\end{array}$ & $\begin{array}{l}\text { passengers; } \\
\text { 2. Leaving a } \\
\text { good } \\
\text { impression } \\
\text { and } \\
\text { building } \\
\text { strong } \\
\text { perception } \\
\text { to make } \\
\text { passenger } \\
\text { aware of } \\
\text { the services } \\
\text { (brand } \\
\text { awareness) } \\
\text { 3. Generating } \\
\text { communica } \\
\text { tion and } \\
\text { luggage } \\
\text { service to } \\
\text { be easy and } \\
\text { convenient }\end{array}$ \\
\hline $\begin{array}{l}\text { Positive } \\
\text { Ambiance }\end{array}$ & $\begin{array}{l}\text { Cleanliness } \\
\text { Efficient } \\
\text { Operation }\end{array}$ & $\begin{array}{l}\text { Airport } \\
\text { Environment }\end{array}$ & $\begin{array}{l}\text { Adding the } \\
\text { availability of } \\
\text { various retail } \\
\text { shop variants, } \\
\text { cafes/ } \\
\text { restaurants, } \\
\text { selling prices at } \\
\text { retail stores and } \\
\text { cafes/restaurants } \\
\text { and the } \\
\text { availability of } \\
\text { local SIM cards } \\
\text { and locker } \\
\text { rentals }\end{array}$ & $\begin{array}{l}\text { Existing } \\
\text { services have } \\
\text { been adjusted }\end{array}$ & \\
\hline
\end{tabular}

Based on Table 4, it explains that the increase in passengers' experiences at airport terminals is driven by airport passengers themselves. Every need, desire, expectation, habit or behavior, and different demands of each airport passenger will affect the characteristics of the airport terminal services. Thus, the development of a passenger activity service model that has been adjusted to the types of business passengers and leisure passengers at Terminal 1 Soekarno-Hatta Airport through the Panca Program can be applied to Terminal 1 of Soekarno-Hatta Airport as a template for the Airport Passenger Experience Model for Low-Cost Carrier Terminals.

\section{Conclusion}

Based on the identification of the needs and expectations of Terminal $1-\mathrm{BSH}$ passengers through the Quality Function Deployment (QFD) method, there are 20 service attributes that have a negative gap value or exceed the average satisfaction threshold. Out of the 50 indicators of passenger activity service processing, it shows that airport passengers are still dissatisfied with the services provided or there is a decrease in the quality-of-service performance. The proportion of passengers' dissatisfaction in the departure service area is higher than in the arrival area. 
Based on the results of the Analytic Hierarchy Process (AHP), airport passenger activity services that will affect the optimization of Terminal 1-BSH service performance are security screening elements of $13.2 \%$, airport access of $11.2 \%$, airport facilities of $10.6 \%$, and check-in / drop baggage $10.5 \%$. These four elements are important for airport passenger activities and can become a reference for determining technical responses based on the level of importance of airport passengers.

The results of the formulation of the House of Quality (HoQ) from a combination of QFD and AHP analysis methods obtain 5 priority programs (Panca Programs) of 17 Needs \& Importance technical responses, including Customer Centric, Strategic Approach to Customer Service, Innovative, Sense of Place and Positive Ambiance. These programs have been adapted to the types of business passengers and leisure passengers at Terminal 1 Soekarno-Hatta Airport as a template for the Airport Passenger Experience Model for Low-Cost Carrier Terminals. If the manager of Terminal 1-BSH can carry out the five priorities of technical responses, it can meet the needs of airport passengers by contributing 53.73\%. Therefore, if the sixth to tenth priority technical response is also carried out, it will increase the airport passenger experience by contributing as much as $84.80 \%$ as optimization of airport service performance at Terminal 1 Soekarno-Hatta Airport 
Airport Passenger Experience Model for Terminal Low-Cost Carrier (Study Case at Terminal 1 Soekarno-Hatta International Airport)

\section{BIBLIOGRAPHY}

Amir, Bilal, \& Ralph, Paul. (2018). There is no random sampling in software engineering research. Proceedings of the 40th International Conference on Software Engineering: Companion Proceeedings, 344-345.

Cohen, Lou. (1995). Quality function deployment: how to make QFD work for you. Prentice Hall.

Fajri, Chalis. (2020). Perancangan Shelter Bus Mebidang Dengan Menggunakan Quality Function Deployment (QFD). Jurnal Sistem Teknik Industri, 22(1), 77-89.

Freeman, Michelle, Baumann, Andrea, Fisher, Anita, Blythe, Jennifer, \& AkhtarDanesh, Noori. (2012). Case study methodology in nurse migration research: An integrative review. Applied Nursing Research, 25(3), 222-228.

Ghozali, Imam. (2016). Aplikasi Analisis Multivariate dengan Program SPSS. Cet . VIII. In Aplikasi Analisis Multivariate dengan Program SPSS. Cet . VIII. Semarang: Badan Penerbitan Universitas Dipanegoro.

Kurniawan, Ridha, Sebhatu, Samuel Petros, \& Davoudi, Sara. (2017). Passengers' perspective toward airport service quality (ASQ)(Case study at Soekarno-Hatta International Airport). Civ. Eng. Forum, 3(1).

Majid, Abdul. (2020). Pengenalan Keselamatan Penerbangan di Lembaga Pendidikan. Jurnal Industri Elektro Dan Penerbangan, 2(3).

Nasution-Patrick, Sangkoyo Indrawan Prabaharyaka Ivan, de Yong, Tantra Rofianisa Nurdin Sherly, Lukito, Tiara Anggita Yulia Nurliani, \& Aziz, Yusni. (2016). VOL. 1: SISTEM.

Popovic, Vesna, Kraal, Ben, \& Kirk, Phil. (2010). Towards airport passenger experience models. Proceedings of the 7th International Conference on Design and Emotion 2010, 1-11. IIT Institute of Design.

Ramírez, Yendery, Cisternas, Luis A., \& Kraslawski, Andrzej. (2017). Application of House of Quality in assessment of seawater pretreatment technologies. Journal of Cleaner Production, 148, 223-232.

Ridhwanullah, Ridhwanullah. (2016). Pengaruh Kualitas Pelayanan terhadap Citra Perusahaan Jasa Penerbangan dengan Kepuasan Pelanggan sebagai Variabel Moderating Pada PT. Lion Mentari Airlines (Survei Pelanggan Lion Air di Bandara Sultan Hasanuddin Makassar). Universitas Islam Negeri Alauddin Makassar.

Simon, Mario, VAn Den DriesT, FrAnK, \& Wilms, T. O. M. (2016). Driving Customer-Centric Growth: A Practical Roadmap: The Pivotal Role of Insights and Analytics In the Customer-Centric Organization. Journal of Advertising Research, 56(2), 159-168.

Sugiyono. (2017). Metode Penelitian Kuantitatif.

Turner, Barry. (2010). International Air Transport Association (IATA). In The Statesman's Yearbook (pp. 45-46). Springer.

Wiredja, Dedy, Popovic, Vesna, \& Blackler, Alethea. (2019). A passenger-centred model in assessing airport service performance. Journal of Modelling in Management. 